RESEARCH SEMINAR IN INTERNATIONAL ECONOMICS

Department of Economics

The University of Michigan

Ann Arbor, Michigan 48109-1220

SEMINAR DISCUSSION PAPER NO. 224

\title{
PRODUCTION EFFECTS OF PRICE- AND COST-BASED ANTI-DUMPING LAWS UNDER FLEXIBLE EXCHANGE RATES*
}

\author{
by \\ Michael P. Leidy \\ University of Arizona \\ and \\ Bernard M. Hoekman
}

General Agreement on Tariffs and Trade

July 1988

"We are grateful to Robert M. Stern for helpful comments on an earlier draft of this paper. Financial assistance was provided by the Ford Foundation in support of a program of research in trade policy at The University of Michigan.

Address correspondence to:

Professor Michael P. Leidy

Department of Economics

The University of Arizona

Tucson, AZ 85721

\section{JAN 2,1989}

The Sumner and Laura Fogstar Library The University of Michigan 



\section{INTRODUCTION}

Dumping is defined in Article VI of the General Agreement on Tariffs and Trade (GATT) as offering a product for sale in export markets at a price below "normal" value. Normal or "fair" value usually is defined as the price charged by a firm in its home market. In the absence of a domestic price (a home market), the highest comparable price charged in third markets or the exporting firm's estimated costs of production may be used to determine normal value. ${ }^{1}$ As a precondition for imposing protection, The GATT Anti-Dumping Code requires not only that dumping be established by an investigating authority, but also that a domestic industry be materially injured, or face the threat of material injury, and that this injury be caused by imports.

Many nations have passed anti-dumping (AD) legislation, and some are intensive users of the instrument. As can be seen from Table 1, major users are Australia, Canada, the European Community, and the United States. It is noteworthy that in the six-year period covered, over $1200 \mathrm{AD}$ cases were initiated in these countries. Most international economists would agree that the rationale for an $\mathrm{AD}$ law and $\mathrm{AD}$ procedures is very weak, probably nonexistent. However, the economic literature focuses on modelling the reasons that firms might find it in their interest to dump, and not on the effect of AD laws on trade patterns and production. ${ }^{2}$ Indeed, the presence of the threat of an $\mathrm{AD}$ action is rarely taken into account. ${ }^{3}$ Thus, in our view an important dimension of the real trading environment is conspicuously absent from the theoretical dumping literature. ${ }^{4}$

The purpose of this paper is to analyze some of the economic incentives set up by $\mathrm{AD}$ legislation. We focus on the production response of an exporting firm to the threat of an $\mathrm{AD}$ action. The model formalizes one way in which the mere passage of an $\mathrm{AD}$

\footnotetext{
1 Under the cost criterion economists generally would define dumping as selling below marginal cost. In practice, presumably in some: part due to the unobservability of marginal costs, average: cost is specified as the standard. For a brief introduction to GATT anti-dumping rules, seo: Stern, Jackson, and Hockman (1987) and Finger (1987). For a lengthior treatment sex: Caine: (1981) or Vermulst (1987).

2 Recent models designed to explain various motives for dumping include: Davies and Mc:Guinness (1982), Ethier (1982), Blair and Cheng (1984), Berhardt (1984), and Hillman and Kat\% (1986).

3 A recent exception is Webb (1987) where the effects of an anti-dumping law on the location of production is cxamined.

4 While several empirical studies have attempted to measure the impact of the threat of an AD action (c.g., Finger (1981), Finger, Hall and Nelson (1982) and Herander and Schwart\% (1984) the model specifications are: somewhat ad hoc, just loosely grounded in a formal theoretical model.
} 
law may constitute "harassment" of foreign firms, harassment that may have a chilling effect on trade similar to other protectionist measures. ${ }^{5}$ The existence of $\mathrm{AD}$ laws and the concomitant threat of an $\mathrm{AD}$ action will cause exporting firms to alter their production and allocation decisions. We show that the exporting firm's reaction to AD laws differs depending on whether a price- or a cost-based definition of dumping is used. In practice it is often uncertain which procedure will be followed, thus making things more difficult for the exporter. The plan of the paper is as follows: Section 2 sets out the model, Section 3 addresses production responses in the short run, while Section 4 analyzes longer run production responses under alternative market structures. We investigate the behavior of the firm under three types of $\mathrm{AD}$ rules: price-based, marginal cost based, and average cost based. While in practice a marginal cost criterion never is used, analysis of this case is, nevertheless, interesting and useful. It is useful because selling below marginal cost probably is the only case where dumping could be construed as predatory. Further, by examining the incentives set up by a marginal cost-based $\mathrm{AD}$ threat our understanding of the effects of price- and average cost based rules is enhanced. It is of interest, therefore, to investigate what the effect of a marginal cost rule would be.

\section{THE MODEL}

In order to examine the effects of $\mathrm{AD}$ laws we need a model of the firm that generates dumping. We choose one where a floating exchange rate generates uncertainty with respect to the value (in home currency) of exports. Thus, we model dumping as a random event. An unexpectedly strong domestic currency tends to bring on $\mathrm{AD}$ actions. ${ }^{6}$ To focus the investigation on the role of price-based versus cost-based AD laws, as well as on the significance of market structure at home and abroad, we assume the firm is risk neutral. This

\footnotetext{
5 The harassmont hypothesis appears to be duc to Gregory (1981) and Finger (1981). Finger (1981, p. 264) makes two points: (1) AD laws proscribe actions by foreign firms that are allowed under laws governing domestic: trade practices; and (2) the costly process of an $A D$ investigation may serve as an import barrier. Finger hypothesizes that the cost of dealing with an $A D$ investigation is higher for forcign firms, and thus that the threat of an action may constitute: harassment of forcign competition. Harassment is not clearly defined in the literature, and one of the goals of this paper is to make this intuitive: notion more concrete.

6 Currency fluctuations have been found to be positively correlated with the number of AD investigations initiated (Dickey, 1982). The kind of dumping we model is consistent with what Viner called "sporadic" dumping. We choose this model of dumping both for convenience and because it allows us to abstract from strategic considerations. Indece, sporadic dumping is singled out specifically in Article II(ii)(b) of the GATT Anti-Dumping Code: as particularly injurious. Dale (1980) points out that the first U.S. anti-dumping law (sections 8n(1)-1 of the Revenue: Act of 1916) wass directed agrainst predatory dumping exclusively. However, because: of the difficulty in establishing predatory intent subsequent legislation includes no mention of the possible: motives of the dumper. Hence, allegations of predation need be no part of an antidumping action.
} 
approach enables us to separate the potentially confounding influence of varying attitudes toward risk from other important determinants of the firm's response to AD legislation. It is assumed that during the market period (ex post) there is no opportunity to reallocate product between markets. To be able to ignore optimal inventory considerations the product is assumed perishable. We also ignore incentives to relocate production facilities across sealed markets.

Following Katz et al. (1982) consider a firm selling in two separate markets: home and abroad. The firm faces a nonstochastic demand function in both markets. However, there exists uncertainty due to a flexible exchange rate. The firm must select its level of production and the allocation of product across markets prior to the resolution of exchangerate uncertainty. Given stable demand in both markets, foreign and domestic prices are known ex ante. What is not known is the domestic currency translation of the foreign price. Under a price-based definition of dumping, if the bilateral exchange rate (the domestic currency price of foreign exchange) realizes sufficiently low (indicating a relatively strong domestic currency) the domestic currency translation of the foreign price will be below the domestic price. ${ }^{7}$ We assume that this triggers an anti-dumping investigation and the imposition of (provisional) measures with certainty. ${ }^{8} \mathrm{An} \mathrm{AD}$ action is modeled in the following way. When an $\mathrm{AD}$ investigation is triggered the foreign authorities impose an $\mathrm{AD}$ duty or otherwise force the firm to remove the dumping margin (i.e., to establish price parity with the home market). We model this as obliging the firm to withdraw sufficient product from the foreign market to remove the dumping margin. ${ }^{9}$

\footnotetext{
7 We will address the effects of a cost-based rule later.

8 In principle, imposition of protection requires a joint showing of less-than-fair-value: (LTFV) pricing and material injury. or the threat of such injury. Imposition of protection is therefore uncertain even given a LTFV finding. Caine (1981, pp. 703 707) has argued that. especially in the U.S., once: LTFV has been established only a minimal showing of injury may be required. While this may be too strong a conclusion, it is supported by the fact that in the U.S. from 1982 through 1985 of 234 completed preliminary injury investigations, 204 extended an affirnative: finding (Destler 1986. appendix B3). Even under a more stringent injury standard the analysis in this paper would not be altered, except to the extent that the foreign firm will not react as strongly. We are comfortable with this assumption both because: we want $t o$ focus on theoretical effects and because: provisional me:asures may be taken quickly and relatively easily. As argued elsewhere, provisional measures may have the same: effect as a final duty (Vermulst, 1987). It should be: pointed out also that the carliest anti-dumping statute: (Canada, 1904: sec: Dals: (1981. p. 12)) was invoked "automatically" in the sense: that injury did not have to be proved. Finally, while: we do not address this issue, a clear rent-gecking incentive exists for import-competing firms to take actions that will increase the likelihood of a finding of injury once LTFV has be:en established.

9 This is done both for convenience and because: it is not unrepresentative of the way AD laws work in practice. GATT rules allow cepporting firms to undertake to remove the durnping margin and thus to avoid an AD duty. The European! Community in particular makes substantial use of these: susponsion agreements (Vermulst, 1987).
} 
For the sake of comparison consider first the behavior of an exporting firm in a world without $\mathrm{AD}$ laws. By assumption the only source of uncertainty is the exchange rate. Therefore the firms problem is to: ${ }^{10}$

$$
\max _{y_{1}, y_{2}} R_{1}\left(y_{1}\right)+E(\tilde{e}) R_{2}^{*}\left(y_{2}\right)-C(y)
$$

where $\mathrm{E}$ is the expectation operator, $\tilde{e}$ is the exchange-rate random variable (defined as the domestic currency price of foreign currency) with known subjective probability distribution, $R_{1}\left(y_{1}\right) \equiv p_{1}\left(y_{1}\right) y_{1}$ is the home revenue function, $R_{2}^{*}\left(y_{2}\right) \equiv p_{2}^{*}\left(y_{2}\right) y_{2}$ is the foreign revenue function in foreign currency units, and $C(y)$ is the cost function in domestic currency units $\left(y=y_{1}+y_{2}\right)$. The solution, of course, satisfies the condition that output is allocated so that marginal revenue in the domestic market and expected marginal revenue abroad just equal marginal cost.

$$
\begin{aligned}
R_{1}^{\prime}\left(y_{1}\right) & =C^{\prime}(y) \\
E(\tilde{e}) R_{2}^{* \prime}\left(y_{2}\right) & =C^{\prime}(y)
\end{aligned}
$$

How does the existence of a price-based $\mathrm{AD}$ law abroad modify the firm's production and allocation decision? Under a price-based definition of dumping every realization of the exchange rate such that $e p_{2}^{\star}\left(y_{2}\right)<p_{1}\left(y_{1}\right)$ triggers an $\mathrm{AD}$ action which results in a mandate of price equalization across the two markets. That is, the authorities in the export market force $e p_{2}^{*}\left(\bar{y}_{2}\right)=p_{1}\left(y_{1}\right)$, where $\bar{y}_{2}<y_{2}$ and $y_{2}$ is the quantity of product sent to the foreign market ex ante. Observe that $\bar{y}_{2}$ is defined by

$$
\bar{y}_{2} \equiv y_{2}\left(\frac{p_{1}\left(y_{1}\right)}{e}\right)
$$

where $y_{2}(\cdot)$ is the foreign demand function. For every realization of $\tilde{e}$ in $\left(0, p_{1}\left(y_{1}\right) / p_{2}^{*}\left(y_{2}\right)\right)$ an $\mathrm{AD}$ action is invoked. For every realization of $\tilde{e}$ between $p_{1}\left(y_{1}\right) / p_{2}^{*}\left(y_{2}\right)$ and infinity (or some finite upper bound) the $\mathrm{AD}$ constraint is nonbinding ex post. This implies the following

\footnotetext{
10 Note that the nonstochastic: cost function does not imply that the firm's inputs are all of domestic: origin. The production decision occurs prior to the market period for output. This imparts uncertainty to the foreign revenue function even under stable foreign demand. Contemporancous spot input prices, on the other hand, are: known whether these factors originate at home: or abroad.
} 
problem for the firm:

$$
\max _{y_{1}, y_{2}} R_{1}\left(y_{1}\right)+\int_{0}^{\frac{m_{1}\left(y_{1}\right)}{\gamma_{2}^{*}\left(y_{2}\right)}} \bar{R}_{2}\left(y_{1}, e\right) d F(e)+R_{2}^{*}\left(y_{2}\right) \int_{\frac{y_{1}\left(y_{1}\right)}{r_{2}^{*}\left(y_{2}\right)}}^{\infty} e d F(e)-C\left(y_{1}+y_{2}\right)
$$

where $F(e)$ is the firm's subjective distribution function for the future spot exchange rate, and $\bar{R}_{2}\left(y_{1}, e\right) \equiv p_{1}\left(y_{1}\right) y_{2}\left(\frac{p_{1}\left(y_{1}\right)}{e}\right)$ is the foreign revenue function when the $\mathrm{AD}$ constraint is binding, with $y_{2}(\cdot)$ being the foreign demand function and $p_{1}\left(y_{1}\right)$ being the inverse demand function in the home market. It is assumed that neither the exporting decision nor the AD action affects the subjective probability distribution of $\tilde{e}^{11}$

Clearly the existence of $\mathrm{AD}$ laws will affect the firm's decision only if at the pre-AD law optimum the $\mathrm{AD}$ constraint is potentially binding. That is, if $y_{1}^{*}$ and $y_{2}^{*}$ solve (1), the $\mathrm{AD}$ law affects the firm's behavior only if $F(e)$ is strictly positive for some $e$ in $\left(0, p_{1}\left(y_{1}^{*}\right) / p_{2}\left(y_{2}^{*}\right)\right)$. If this is not true the firm's problem is unchanged by the introduction of an AD law. From here on we assume that the $\mathrm{AD}$ law is relevant to firm behavior. The necessary conditions for optimality in the presence of a potentially binding $\mathrm{AD}$ law can be written as ${ }^{12}$

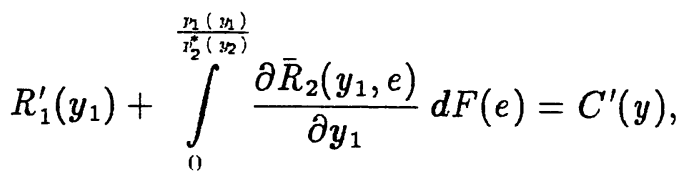

$$
\begin{aligned}
& R_{2}^{\star \prime}\left(y_{2}\right) \int_{\frac{r_{1}\left(y_{1}\right)}{v_{2}^{*}\left(y_{2}\right)}}^{\infty} e d F(e)=C^{\prime}(y) .
\end{aligned}
$$

The intuition underlying expressions (6) and (7) is straightforward. Notice that the marginal revenue associated with an increase in domestic output contains a term not present in (2). This term reflects the increment to revenue earned by selling each constrained unit abroad at a somewhat lower price than otherwise, and so at a price somewhat closer to the unconstrained optimum. That is, by adjusting domestic output the firm can trade off revenue in the home market against expected revenue abroad in the event of an AD action.

\footnotetext{
11 The firm perceives itself to be economically small in this sense.

12 Because the integrands $R_{2}\left(y_{1}, e\right) \equiv p_{1}\left(y_{1}\right) y_{2}\left(\frac{m_{1}\left(y_{1}\right)}{e}\right)$ and $R_{2}^{*}\left(y_{2}\right) e$ are equal at the limit of integration where the AD law becomes binding, the terms involving differentiation of the limits of integration cancel.
} 
It can be shown that the integrand $\partial \bar{R}_{2}\left(y_{1}, e\right) / \partial y_{1}$ is positive for all $e$ in the relevant range if demand is linear in the foreign market. ${ }^{13}$ This implies that the firm has an incentive to exceed the unconstrained optimum in the home market for any given level of production. By doing so the firm tends to mitigate the damages associated with an ex post $\mathrm{AD}$ action as well as to reduce the probability of a LTFV finding. The exporting firm's capacity to ameliorate its condition under the $\mathrm{AD}$ threat by adjusting domestic supply is the principle characteristic that distinguishes price-based from average cost based $\mathrm{AD}$ laws. This tendency will be identified as the exporter's home-market effect.

A second independent effect of the price-based $\mathrm{AD}$ law is that the expected marginal revenue in the foreign market declines for any given level of $y_{2}$. This occurs since the marginal revenue of $y_{2}$ is zero over an entire range of possible exchange-rate realizations. When the $\mathrm{AD}$ constraint is binding, ex ante variations in $y_{2}$ have no effect on the revenue earned in that market ex post. The firm, therefore, has an incentive to reduce shipments to the foreign market for any given level of total production and domestic supply. Since the objective of anti-dumping legislation can only be to protect nascent or established domestic industries, to the extent that the $\mathrm{AD}$ threat induces exporters to recoil from the foreign market this objective is advanced. Observe, however, that the home-market effect serves to circumvent rather than to further the objective of protection. To the extent that exporting firms are able to concentrate their response to the $A D$ threat in the home market, the

13 This can be seen as follows:

$$
R_{2}\left(y_{1}, c\right) \equiv p_{1}\left(y_{1}\right) y_{2}\left(\frac{p_{1}\left(y_{1}\right)}{e}\right)
$$

Hence,

$$
\begin{aligned}
\frac{\partial R_{2}}{\partial y_{1}} & =p_{1}^{\prime}\left(y_{1}\right) y_{2}\left(\frac{p_{1}\left(y_{1}\right)}{e}\right)+p_{1}\left(y_{1}\right) y_{2}^{\prime} \frac{1}{e} p_{1}^{\prime}\left(y_{1}\right) \\
& =p_{1}^{\prime}\left(y_{1}\right)\left[y_{2}\left(\frac{p\left(y_{1}\right)}{e}\right)+\frac{p_{1}\left(y_{1}\right)}{e} y_{2}^{\prime}\right] \\
& =p_{1}^{\prime}\left(y_{1}\right) y_{2}\left(\frac{p_{1}\left(y_{1}\right)}{e}\right)\left[1+\frac{d y_{2}}{d p_{2}^{*}} \cdot \frac{p_{2}^{*}}{y_{2}}\right]
\end{aligned}
$$

since in the constrained region $p_{1}\left(y_{1}\right) / e=p_{2}^{*}$. Note that

$$
\eta^{*} \equiv \frac{d y_{2}}{d p_{2}^{*}} \cdot \frac{p_{2}^{*}}{y_{2}}
$$

is the forcign elasticity of demand evaluated at the constrained level of supply $y_{2}=y_{2}\left(p_{1}\left(y_{1}\right) / e\right)$. Now since the unconstrained level of forcign supply must be: in the eliastic: region of foreign demand and since constrained supply is less than unconstrained, under lincar demand $\left|\eta^{*}\right|>1$ in the relevant region of forcign demand. And conditional on the firm having some: market power at home: (so that $p_{1}^{\prime}<0$ ), this establishes the claim. If the firm is a price taker domestically the integrand is simply mero. 
threat, though credible, fails to achieve the desired outcome.

How do things change if cost-based rules are followed? In this case, we assume an $\mathrm{AD}$ action is triggered whenever the exchange-rate adjusted foreign price is below costs of production. Costs can be defined as average total costs or as marginal costs. In practice, perhaps in part due to the unobservability of marginal costs, average total costs are taken as the criterion. ${ }^{14}$ In what follows we will examine both possibilities. This is because analysis of the effect of a rule based on marginal cost is of interest in its own right, and because the average cost rule is a special case of a marginal cost rule. The analysis based on the long run average total cost is equivalent to assuming constant marginal cost if the investigation aims to determine the minimum of the long run average total cost schedule. ${ }^{15}$ Thus, an $\mathrm{AD}$ action is taken with certainty whenever the exchange-rate adjusted foreign price realizes below the firm's marginal cost or average total cost, depending on which rule is being implemented. As before, when an $\mathrm{AD}$ action is invoked the firm is required to adjust foreign price to eliminate the dumping margin.

Consider a marginal cost $\mathrm{AD}$ law first. If $e p_{2}^{*}\left(y_{2}\right)<C^{\prime}(y)$ an anti-dumping action is taken. This forces the firm to achieve $e p_{2}^{*}\left(\bar{y}_{2}\right)=C^{\prime}(y)$, where $\bar{y}_{2}<y_{2}$. The firm's expected profit maximization problem is:

$$
\max _{y_{1}, y_{2}} R_{1}\left(y_{1}\right)+\int_{0}^{\frac{C(y)}{r_{2}^{(2)}\left(y_{2}\right)}} \hat{R}_{2}(y, e) d F(e)+R_{2}^{\times}\left(y_{2}\right) \int_{\frac{C(y)}{\gamma_{2}^{*}(32)}}^{\infty} e d F(e)-C(y)
$$

where

$$
\hat{R}_{2}(y, e) \equiv y_{2}\left(\frac{C^{\prime}(y)}{e}\right) \cdot C^{\prime}(y)
$$

\footnotetext{
14 U.S. law speaks of fully allocated costs of production.

15 It should be noted that, in contrast to the price-based definition, a violation of a cost-based AD law is not readily observable by the forcign authorities. In what follows we make the (heroic) assumption that the firm's cost schedules can be observed.
} 
It can be shown that ${ }^{16}$

$$
\frac{\partial \hat{R}_{2}}{\partial y}=C^{\prime \prime}(y) \cdot \bar{y}_{2} \cdot\left(1+\eta^{*}\right),
$$

where $\bar{y}_{2} \equiv y_{2}\left(\frac{C^{\prime}(y)}{e}\right)$ is the constrained foreign supply given an $\mathrm{AD}$ action and $\eta^{*}$ is the foreign elasticity of demand at $\bar{y}_{2}<y_{2}$. If the foreign demand curve is linear the foreign elasticity of demand at $\bar{y}_{2}$ must be such that $\left|\eta^{*}\right|>1$. This is true since $\bar{y}_{2}<y_{2}$ and the firm's ex ante foreign supply must be in a region of elastic demand. Hence, we see that for any realization of $\tilde{e}$ in the lower range the following must be true:

$$
\frac{\partial \hat{R}_{2}}{\partial y} \begin{cases}>0, & \text { if } C^{\prime \prime}<0 \\ =0, & \text { if } C^{\prime \prime}=0 \\ <0, & \text { if } C^{\prime \prime}>0\end{cases}
$$

The first-order conditions for (8) are: ${ }^{17}$

$$
\begin{array}{r}
R_{1}^{\prime}\left(y_{1}\right)+\int_{0}^{\frac{C^{\prime}(y)}{\gamma_{2}^{\prime}\left(y_{2}\right)}} \frac{\partial \hat{R}_{2}(y, e)}{\partial y} d F(e)=C^{\prime}(y) \\
\int_{0}^{\frac{C^{\prime}(y)}{\gamma_{2}^{\prime}\left(y_{2}\right)}} \frac{\partial \hat{R}_{2}(y, e)}{\partial y} d F(e)+R_{2}^{* \prime}(y) \int_{\frac{C^{(}(y)}{r_{2}^{\prime}\left(y_{2}\right)}}^{\infty} e d F(e)=C^{\prime}(y) .
\end{array}
$$

The integral expression common to (12) and (13) indicates that the firm's marginal revenue in each market depends on the sensitivity of marginal cost to variations in output. Adjusting output affects marginal revenue through the marginal-cost channel by altering the (subjective) probability that an $\mathrm{AD}$ action will be taken and by affecting the price to be imposed in the foreign market should an $\mathrm{AD}$ action occur. If $C^{\prime \prime}<0$, the same qualitative effect pertains as under a price-based law. ${ }^{18}$ Note that if, as in practice, an average cost rule is followed, the threshold at which the $\mathrm{AD}$-constraint becomes binding is independent of the firm's level of production. Even so, output for the foreign market must fall. This can

16 Differentiating (9) with respect to $y$ yickds:

$$
\begin{aligned}
\frac{\partial \hat{R}_{2}(y, c)}{\partial y} & =C^{\prime \prime} y_{2}+C^{\prime} \frac{d y_{2}}{d p_{2}^{*}} \cdot \frac{C^{\prime \prime}}{c}, \\
& =C^{\prime \prime} y_{2}\left(1+\eta^{*}\right)
\end{aligned}
$$

sincs $C^{\prime} / e=p_{2}^{*}$ under the $\mathrm{AD}$ constraint.

17 As in the pricc-based problem, the derivatives involving the limits of integration cancel.

18 If $C^{\prime \prime}=0$ (constant $\mathrm{MC}$ ), the passage of cost-based $\mathrm{AD}$ legislation abroad affects firm bohavior in a mannor analogous to a downward adjustment in exchange-rate expectations. 
be demonstrated as follows. Assuming the firm has market power at home and abroad (the textbook case), prior to the imposition of the $\mathrm{AD}$ law the firm allocates output to satisfy expressions (2) and (3). With $C^{\prime \prime}=0$ the first-order conditions after the imposition of a cost-based $\mathrm{AD}$ law are: ${ }^{19}$

$$
\begin{aligned}
R_{2}^{* \prime}\left(y_{2}^{*}\right) \int_{C^{\prime} / p_{2}^{*}\left(y_{2}^{*}\right)}^{\infty} e d F(e) & =C^{\prime} .
\end{aligned}
$$

Since $C^{\prime}$ is constant, $y_{1}$ is unchanged by the $\mathrm{AD}$ law. The home market is, in this sense, insulated from the foreign $\mathrm{AD}$ law. However, there is a tendency for the quantity supplied to the foreign market to fall. As long as the pre-AD law optimum is such that the subjective probability density function of $\tilde{e}$ has some density below $C^{\prime} / p_{2}^{*}\left(y_{2}^{*}\right)$, we know that

$$
\int_{C^{\prime} / p_{2}^{*}\left(y_{2}^{*}\right)}^{\infty} e d F(e)<E(\tilde{e}) .
$$

Hence, at the pre-AD law optimal value of the foreign allocation, $y_{2}^{*}$, we have

$$
R_{2}^{* \prime}\left(y_{2}^{*}\right) \int_{C^{\prime} / p_{2}^{*}\left(y_{2}^{*}\right)}^{\infty} e d F(e)-C^{\prime}<0 .
$$

Thus, $y_{2}^{\times}$overshoots the post-AD law optimum. Under constant marginal cost, therefore, the firm's output falls by the full amount of its reduced shipments to the foreign market and supply to the exporter's home market is unaffected. While the exporter's home market is not directly affected under these circumstances, important general equilibrium effects are suggested. Since production declines for every representative exporting firm, the threat of $\mathrm{AD}$ actions may have a significant contractionary effect on the exporter's macroeconomy. Although such conclusions are formally outside the scope of the present model, this conjecture is consistent with the reduction in the gains from trade following the erection of other, more traditional, barriers to trade observed in neoclassical trade models.

An $\mathrm{AD}$ law based on the firm's minimum long-run average total cost (LRATC) is equivalent to a marginal-cost based law only under constant costs. The problem of a firm

\footnotetext{
19 See cquations (12) and (13) and the prior discussion involving the sign of $\partial \hat{R} / \partial y$.
} 
facing a minimum-LRATC-based AD law is to solve:

$$
\max _{y_{1}, y_{2}} R_{1}\left(y_{1}\right)+\int_{0}^{C / p_{2}^{*}\left(y_{2}\right)} \Re_{2}(\bar{C}, e) d F(e)+R_{2}^{*}\left(y_{2}\right) \int_{C / p_{2}\left(y_{2}\right)}^{\infty} e d F(e)-C\left(y_{1}+y_{2}\right),
$$

where $\Re_{2}(\bar{C}, e) \equiv \bar{C} \cdot y_{2}(\bar{C} / e)$ is the foreign revenue function when the $\mathrm{AD}$ constraint is binding, and $\bar{C}$ is the minimum LRATC. The solution of (18) satisfies $^{20}$

$$
\begin{aligned}
R_{2}^{* \prime}\left(y_{2}\right) \int_{C / p_{2}^{*}\left(y_{2}\right)}^{\infty} e d\left(y_{1}\right) & =C^{\prime}(y)
\end{aligned}
$$

Observe that the first-order conditions here are equivalent to (14) and (15) if, and only if, marginal cost is constant. Otherwise, the exporter's home market is affected indirectly by the imposition of the cost-based $\mathrm{AD}$ law. In particular, while production falls, supply at home increases if $R^{\prime \prime}<0$ and $C^{\prime \prime}>0$. This is shown in Figure 1.

The curve labeled \#1 in Figure 1 indicates combinations of $y_{1}$ and $y_{2}$ that satisfy equation (2). That labeled \#2 denotes combinations of $y_{1}$ and $y_{2}$ that satisfy equation \#3. Point $\mathrm{A}$ shows the pre-AD law equilibrium production and allocation values for $y_{1}$ and $y_{2}$. The imposition of an AD law based on the minimum LRATC has no effect on the position of the \#1 curve since equations (2) and (19) are identical. However, expression (20) indicates that the imposition of the $\mathrm{AD}$ law reduces the marginal revenue associated with $y_{2}$. Equation (20) can be satisfied only if the value of $y_{1}$ is reduced for any given level of $y_{2}$. That is, the curve representing values of $y_{1}$ and $y_{2}$ that satisfy (20) must be everywhere to the left of the \#2 curve. The leftward shift, of course, will not in general be parallel. The AD-law equilibrium is at point $\mathrm{B}$, where production has declined, domestic output has increased and exports have declined by more than domestic output has risen.

In the rest of the paper we continue to focus on the output response of the exporting firm. As this is unclear in general, a number of special cases are investigated. The definition of dumping and the role of market structure at home and abroad are crucial to determining

20 Again, the: terms involving differentiation of the limits of integration cancel, and the partials of $R_{2}$ with respect to $y_{1}$ and $y_{2}$ are both $\%:$ ro. 
the firm's response to an $\mathrm{AD}$ constraint. We will proceed by examining first the production response in the short run.

\section{PRODUCTION RESPONSE IN THE SHORT RUN}

Suppose that a foreign $\mathrm{AD}$ law is imposed abruptly (with surprise) at a time when product has been shipped abroad, but there is still opportunity to adjust the level of production upward. That is, the $\mathrm{AD}$ law is imposed prior to the market period. As the quantity of product shipped to the foreign market is perceived to be sunk, the firm's only intra-period ex ante control variable is the quantity of product to be offered in the home market. ${ }^{21}$

We continue to treat the firm's cost function as depending on total output for the period. ${ }^{22}$ It is assumed that there is no updating of the subjective distribution of $\tilde{e}$ as the market period approaches. This means that a firm not anticipating impending AD legislation has no incentive to postpone the production decision and may need to make this decision at the beginning of the period in order to make its foreign shipments. Under these conditions the firm's intra-period (or short-run) response to the surprise passage of an $\mathrm{AD}$ law abroad can only involve changing its output for the home market. In this sense, the home-market effect is isolated and it alone drives the results.

Prior to the $\mathrm{AD}$ law the firm will have chosen production and allocated output to satisfy equations (2) and (3). Say that $y_{1}^{*}$ and $y_{2}^{*}$ solve the original problem. The firm's intra-period problem after the surprise adoption abroad of a price-based AD law is:

$$
\max _{y_{1} \geq y_{1}^{*}} R_{1}\left(y_{1}\right)-C\left(y_{1}+y_{2}^{*}\right)+\int_{0}^{\frac{m_{1}\left(\frac{n}{2}\right)}{r_{2}^{*}\left(\frac{i_{2}}{2}\right)}} \bar{R}_{2}\left(y_{1}, e\right) d F(e)+R_{2}^{*}\left(y_{2}^{*}\right) \int_{\frac{m(n)}{r_{2}^{*}\left(\frac{n}{2}\right)}}^{\infty} e d F(e)
$$

The firm's updated production and home-supply response is determined by

$$
R_{1}^{\prime}\left(y_{1}\right)+\int_{0}^{\frac{y_{1}(3 n)}{\gamma_{2}^{*}\left(\frac{3 n}{2}\right)}} \frac{\partial \bar{R}_{2}\left(y_{1}, e\right)}{\partial y_{1}} d F(e)=C^{\prime}\left(y_{1}+y_{2}^{*}\right)
$$

\footnotetext{
21 The analysis is the same if instead of passing a new AD law, cxisting legislation that had been unenforced is now perceived to be binding.

22 Strictly speaking, in order for the cost function to remain constant intra-period we require stable input prices. This is no problem if the firm purchases its inputs domestically. While this assumption is not required in the analysis of other sections, in the the short-run investigation of this section we do assume that inputs are supplied dornestically.
} 
But, as shown previously $\partial \bar{R}_{2}\left(y_{1}, e\right) / \partial y_{1}>0$ for all $e$ in $\left(0, p_{1}\left(y_{1}\right) / p_{2}^{*}\left(y_{2}^{*}\right)\right)$. This implies that at the pre-shock levels $\left(y_{1}^{*}, y_{2}^{*}\right)$ the marginal revenue of domestic supply exceeds the marginal cost. The firm, therefore, acts to increase production for the home market. By doing so the domestic price that will prevail in the market period is driven down. Increasing supply in the home market improves the firm's position in two ways. It reduces the probability that an $\mathrm{AD}$ action will be taken by lowering the threshold at which price-based dumping occurs. It also reduces the quantity of product that must be pulled from the foreign market (and consequently perishes) in the event of an $\mathrm{AD}$ action. Thus, the surprise imposition of a price-based $\mathrm{AD}$ law, or alternatively any change in the political environment that reveals existing legislation will now be enforced, induces the exporting firm in the short run to increase production and to "dump" it in the home market. This perverse production response is a stopgap measure that lasts only until the end of the period. It is identified as preemptive home dumping.

Now suppose the firm faces a cost-based definition of dumping. Then the adjustment taken above may be inappropriate. Above, the idea was to increase output in the home market to drive down the domestic price. This lowered the likelihood of an $\mathrm{AD}$ action being taken and, if taken, allowed greater sales abroad than otherwise. Under a cost-based $\mathrm{AD}$ rule, this same firm with everywhere increasing marginal cost would actually like to decrease output. If it were possible to do so the applicable level of marginal cost could be reduced. But the production level cannot be reduced (production has already occurred), it can only increase intra-period. When the firm's marginal cost is everywhere falling, the optimal response is to step up production beyond the pre-AD law optimum in order to reduce the applicable level of marginal cost. Thus the response under declining marginal cost is quite analogous to the price-based example above. Increasing production has the effect of reducing the probability of an $\mathrm{AD}$ action as well as reducing the quantity of product that must be withdrawn from the foreign market when an $\mathrm{AD}$ action is triggered.

To see this consider again the first-order conditions in the absence of an AD law given by (2) and (3). With the passage of a marginal cost-based $\mathrm{AD}$ law the intra-period problem 
confronting the firm is:

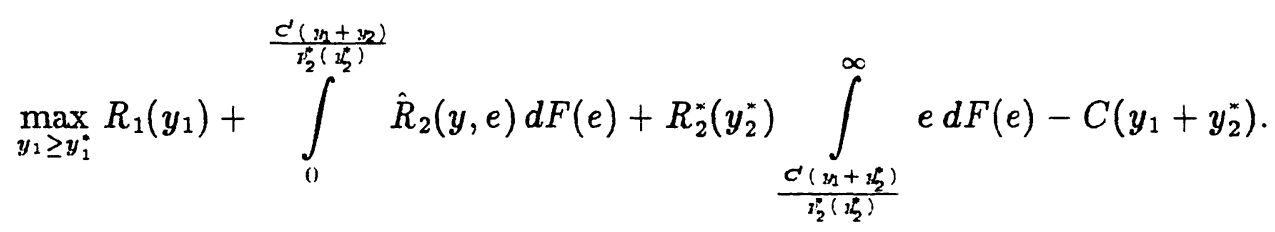

Domestic output is chosen to satisfy

$$
R_{1}^{\prime}\left(y_{1}\right)+\int_{0}^{\frac{C^{\prime}\left(y_{1}+y_{2}^{*}\right)}{r_{2}^{*}\left(y_{2}^{*}\right)}} \frac{\partial \hat{R}_{2}(y, e)}{\partial y} d F(e)-C^{\prime}\left(y_{1}+y_{2}^{*}\right) \leq 0 .
$$

Note that $y_{1}=y_{1}^{*}$ satisfies (2) so that $R_{1}^{\prime}\left(y_{1}^{*}\right)=C^{\prime}\left(y_{1}^{*}+y_{2}^{*}\right)$. If $C^{\prime \prime} \geq 0$ everywhere, then the integrand in (24) is nonpositive for all $e$ and the condition in (24) is met at $y_{1}=y_{1}^{*}$. In fact, under nondecreasing marginal costs the firm would like to be able to reduce production below the previously set level but cannot since this amount is sunk. If instead marginal cost is everywhere decreasing, then the integrand in (24) is positive for all $e$ indicating that (24) fails at the pre-AD law solution. The firm should increase output and, by so doing, reduce the marginal cost of production.

Hence, if $C^{\prime \prime} \geq 0$, the intra-period response is to do nothing. If instead $C^{\prime \prime}<0$, stepping up production and driving down marginal cost can mitigate the expected damages associated with the new $\mathrm{AD}$ law. Observe that an $\mathrm{AD}$ law expressed in terms of the minimum long-run average total cost leaves the firm powerless to affect the dumping margin by adjusting domestic output. The optimal short-run response is again to do nothing. Under an average cost $\mathrm{AD}$ rule the home market effect is always absent. This leaves the firm without an instrument to lessen its exposure to the $\mathrm{AD}$ threat in the short run.

\section{LONG RUN PRODUCTION RESPONSES: SPECIAL CASES}

\subsection{No Domestic Market}

At times a firm produces entirely for export, with no domestic market for its good. Assuming no third market data exist, a firm producing exclusively for export only can be subject to a cost-based $\mathrm{AD}$ law. Assume that an $\mathrm{AD}$ action is taken against the firm if it 
is found to be selling in the foreign market below its marginal cost of production. Prior to the imposition of the $\mathrm{AD}$ law the firm chooses production to equate expected marginal revenue and marginal cost. The passage of a cost-based AD law modifies the firm's output decision as follows:

$$
\max _{y} \int_{0}^{C^{\prime}(y) / p_{2}^{*}(y)} \hat{R}(y, e) d F(e)+R_{2}^{*}(y) \int_{C^{\prime}(y) / p_{2}^{*}(y)}^{\infty} e d F(e)-C(y) .
$$

The post-AD law production decision satisfies:

$$
\int_{0}^{C^{\prime}(y) / p_{2}^{*}(y)} \frac{\partial \hat{R}(y, e)}{\partial y} d F(e)+R_{2}^{\times \prime}(y) \int_{C^{\prime}(y) / p_{2}^{*}(y)}^{\infty} e d F(e)=C^{\prime}(y)
$$

As mentioned previously, the sign of the integrand $\partial \hat{R} / \partial y$ depends on whether marginal cost is increasing, decreasing, or constant. If $C^{\prime \prime} \geq 0$ then $\partial \hat{R} / \partial y \leq 0$ for all $y$ and $e$. Everywhere nondecreasing marginal cost is sufficient to conclude that the firm will reduce output in response to the imposition of a cost-based $A D$ law. That is, at the pre- $A D$ law optimum, $y^{*}$, we know that

$$
\int_{0}^{C^{\prime}\left(y^{*}\right) / p_{2}^{*}\left(y^{*}\right)} \frac{\partial \hat{R}(y, e)}{\partial y} d F(e)+R_{2}^{\times \prime}(y *) \int_{C^{\prime}\left(y^{*}\right) / p_{2}^{*}\left(y^{*}\right)}^{\infty} e d F(e)-C^{\prime}\left(y^{*}\right)<0
$$

as long as marginal cost is everywhere nondecreasing. By reducing production the probability of an $\mathrm{AD}$ action being taken falls and, if taken, the mandated product withdrawal is not as great as it would have been otherwise. If marginal cost declines sharply as output is reduced below $y^{*}$ then the required downward adjustment will be quite small. Under such circumstances the firm is able to adapt to the $\mathrm{AD}$ law with minimal effect on price in the foreign market. The adjustment is manifested principally in a decline in the firm's marginal cost of production rather than in a sharp increase in foreign price. If a firm's marginal costs rise sharply in a neighborhood of the pre- $\mathrm{AD}$ optimum, therefore, the $\mathrm{AD}$ law does little to protect import-competing firms in the foreign market.

Suppose instead that the firm operates under declining marginal costs. The integrand $\partial \hat{R} / \partial y$ is then positive for all $e$ and $y$. Declining marginal costs seems to open up the 
possibility that output can expand in response to the $\mathrm{AD}$ law. In particular, if under some circumstances it can occur that

$$
\int_{0}^{C^{\prime}\left(y^{*}\right) / p_{2}^{*}\left(y^{*}\right)} \frac{\partial \hat{R}(y, e)}{\partial y} d F(e)>R_{2}^{* \prime}(y) \int_{0}^{C^{\prime}\left(y^{*}\right) / p_{2}^{*}\left(y^{*}\right)} e d F(e),
$$

then the optimal response is to increase production. It is clear that this condition cannot be satisfied if marginal cost is declining just slightly. Further, sharply decreasing marginal cost is ruled out by the pre- $\mathrm{AD}$ law second-order conditions. Although it is not clear whether this restriction on the rate of decline in $\mathrm{MC}$ is sufficient to rule out an optimal expansion of output, it appears that under declining marginal cost the incentive to cut back production is diminished and, if a production cut back is called for, the extent of the reduction will be less than had marginal cost not been declining. As production is cut back, following the desired reduction in shipments to the foreign market, this has the countervailing effect of driving up marginal cost. Other things equal, higher $\mathrm{MC}$ increases the firm's exposure to the $\mathrm{AD}$ threat. Hence the effectiveness of pulling product from the foreign market in order to lessen the $A D$ threat by driving up the export price is partially defeated by the increase in marginal cost that accompanies a decline in production when the MC curve is negatively sloped. When marginal cost is rising, on the other hand, a decline in production reinforces the desirable effect of shifting away from the foreign market.

\subsection{Domestic Market Power and Perfect Competition Abroad}

Under a price-based definition of dumping and perfect competition in the foreign market, prices abroad cannot be affected by an $\mathrm{AD}$ action. In the face of an $\mathrm{AD}$ action the exporting firm has no choice but to withdraw entirely from the foreign market ex post. ${ }^{23}$ That is, the exporter earns revenue for product shipped abroad only if dumping does not occur. ${ }^{24}$ Prior to the imposition of the AD law the firm chooses total output to equate

23 We realize that using $\mathrm{AD}$ legislation if there exists perfect competition in the importing market is manifestly irrational on the part of the imposing regime. Nevertheless, as an excercise it has independent analytical value, and leads to some useful insights regarding the cffects of an $A D$ law.

24 The timn's problem in this case: is to:

$$
\max _{y_{1}, y_{2}} R_{1}\left(y_{1}\right)+p_{2}^{*} y_{2} \int_{\frac{m(n)}{p_{2}^{*}}}^{\infty} c d F(c)-C\left(y_{1}+y_{2}\right)
$$


$p_{2}^{*} E(\tilde{e})$ with marginal cost. The optimal allocation of output is then established by choosing domestic output so that $R_{1}^{\prime}\left(y_{1}\right)=C^{\prime}(y)$. Figure 2 shows the pre-AD law combinations of $y_{1}$ and $y_{2}$ satisfying

$$
R_{1}^{\prime}\left(y_{1}\right)=C^{\prime}(y)
$$

and

$$
p_{2}^{*} E(\tilde{e})=C^{\prime}(y)
$$

in the curves labeled \#1 and \#2 respectively. Observe that the slope of the \#2 curve is negative one while the slope of the \#1 curve is less than one in absolute value. ${ }^{25}$

The existence of price-based AD legislation implies the following first-order conditions for the firm:

$$
\begin{aligned}
& R_{1}^{\prime}\left(y_{1}\right)-\bar{e}\left(y_{1}, p_{2}^{*}\right) p_{2}^{*} y_{2} f(\bar{e}) \frac{\partial \bar{e}\left(y_{1}, p_{2}^{*}\right)}{\partial y_{1}}=C^{\prime}(y) \\
& p_{2}^{*} \int_{\frac{m_{1}\left(y_{1}\right)}{r_{2}^{*}}}^{\infty} e d F(e)=C^{\prime}(y) .
\end{aligned}
$$

where $\bar{e}\left(y_{1}, p_{2}^{\star}\right) \equiv p_{1}\left(y_{1}\right) / p_{2}^{*}$ is the threshold exchange rate at which the AD law will be just binding. The middle element in expression (31) is negative. This term reflects the marginal value of $y_{1}$ due to the diminished likelihood that an $\mathrm{AD}$ action will be taken as increases in $y_{1}$ depress the domestic price. This indicates that any combination of $y_{1}$ and $y_{2}$ satisfying (29) leaves (31) strictly positive. The locus of points in $\left(y_{1}, y_{2}\right)$ space satisfying (31) must, therefore, be everywhere to the right of the \#1 curve in Figure $2 .{ }^{26}$ Still assuming the $\mathrm{AD}$ law is perceived to be potentially binding, we observe that any combination of $y_{1}$ and $y_{2}$ satisfying (30) leaves (32) strictly negative. The locus of points satisfying (32) must, therefore, be everywhere to the left of the \#2 curve in Figure 2. The post AD optimum is, then, to the left of the \#2 locus. Because the slope of the \#2 locus is minus one we know that total output must fall. Further, there will tend to be a rather forceful shift of remaining production toward the home market.

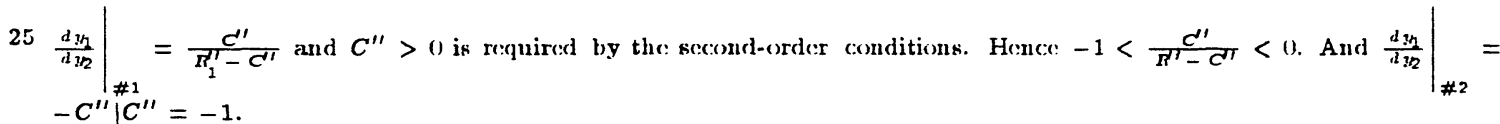

26 This assumes $e\left(y_{1}, p_{2}^{*}\right) p_{2}^{*} y_{2} f(c) \frac{\theta e\left(y_{1}, y_{2}^{*}\right)}{\partial_{11}}$ is well-behaved in the sense that the objective function is concave.
} 


\subsection{Perfect Competition at Home, Market Power Abroad}

In this section the firm is assumed to be facing perfect competition in the home market, but to have exclusive access to a foreign market in which it can exercise market power. ${ }^{27}$ In the absence of an $\mathrm{AD}$ law the firm allocates output so that the price in the domestic market is just equal to the expected marginal revenue abroad. When facing a price-based $\mathrm{AD}$ law the firm optimizes over $y_{1}$ and $y_{2}$ according to:

$$
\max _{y_{1}, y_{2}} p_{1} y_{1}+\int_{0}^{p_{1} / p_{2}^{*}\left(y_{2}\right)} p_{1} y_{2}\left(\frac{p_{1}}{e}\right) d F(e)+R_{2}^{*}\left(y_{2}\right) \int_{p_{1} / p_{2}^{*}\left(y_{2}\right)}^{\infty} e d F(e)-C(y) \text {. }
$$

The first-order conditions are:

$$
\begin{aligned}
p_{1} & =C^{\prime}(y) \\
R_{2}^{\times \prime}\left(y_{2}\right) \int_{p_{1} / p_{2}^{*}\left(y_{2}^{*}\right)}^{\infty} e d F(e) & =C^{\prime}(y) .
\end{aligned}
$$

The firm's optimal response to the imposition of a price-based AD law is indicated in Figure $3 .{ }^{28}$ The \#1 curve represents combinations of $y_{1}$ and $y_{2}$ that solve $p_{1}=C^{\prime}(y)$. It is a line whose slope is negative one. This implies that total production is constant along the \#1 curve. The \#2 curve represents combinations of $y_{1}$ and $y_{2}$ that solve $R_{2}^{* \prime}\left(y_{2}\right) E(\tilde{e})=C^{\prime}(y)$. Its slope is necessarily less than negative one. The post-AD law first-order conditions indicate that the \#1 curve is unchanged and that the \#2 curve is everywhere to the left of the pre-AD law \#2 curve. Together these imply that $\Delta y=0$, with $\Delta y_{1}>0$ and $\Delta y_{2}=-\Delta y_{1}$. The firm's optimal level of production is, therefore, unaffected by the imposition of an AD law. Only the allocation of output across markets is changed.

The existence of a domestic competitive market establishes an optimal level of production irrespective of market conditions abroad, as long as the $\mathrm{AD}$ law is price based. ${ }^{29}$

27 This could be due to the need to acquire an export license, for example.

28 Note that the intra-period response of this firm is $\Delta y_{1}=0$. This occurs since a change in domestic: output effects neither the probability of dumping nor the the cost of an $A D$ action should it be taken. This derives, of course, from the inability of the firm to affect the home: price. which elininates any control it might have otherwise had orer the likelihood of an $\mathrm{AD}$ action. The honne market effect is absent unless the exporter has some market power domestically.

29 That the tendency to recoil from the forcign market in favor of the domestic: market has no effect on domestic: prics: is a function of assuming that just one firm is affected by the AD law. Of course, if many of these competitive firms have: access to separate forcign markets, then a simultaneous (perhaps a coordinated) move: to impose price-based AD legislation in cach of these forcign markets may tend to depress the domestic: price: as these: firms all reallocate: product to the home: inarket. Such a price effect would then lead to reduced output. This secms rather unlikely, however. 
Under a marginal cost-based definition the production incentives set up by $A D$ legislation are a bit different. In contrast to the price-based case, adjusting total production in such a way as to reduce marginal cost diminishes the likelihood that an $\mathrm{AD}$ action will be taken, holding $y_{2}$ constant. It does this by reducing the threshold at which a cost-based AD action is triggered.

To see this, consider the post-AD law necessary conditions for optimality. Modifying expression (12) to reflect perfect competition in the home market and reproducing (13) for convenience we obtain:

$$
\begin{aligned}
& p_{1}+\int_{0}^{\frac{C(y)}{r_{2}^{\prime}(y / 2)}} \cdot \frac{\partial \hat{R}_{2}(y, e)}{\partial y} d F(e)=C^{\prime}(y) \\
& \int_{0}^{\frac{C^{\prime}(y)}{\gamma_{2}^{\prime}(y, y)}} \frac{\partial \hat{R}_{2}(y, e)}{\partial y} d F(e)+R_{2}^{* \prime}\left(y_{2}\right) \int_{\frac{C(y)}{\Gamma_{2}^{\prime}(y 2)}}^{\infty} e d F(e)=C^{\prime}(y)
\end{aligned}
$$

The analysis is simplified by assuming that $C^{\prime \prime}>0$ for all $y$. By expression (11) the integrand $\partial \hat{R}_{2} / \partial y<0$ for all $y$ and $e$ in the interval $\left(0, C^{\prime} / p_{2}^{\times}\left(y_{2}\right)\right)$. The existence of a costbased $\mathrm{AD}$ law thus imposes a new cost associated with production which is represented by the integral expression common to both equations.

The optimal production response is analyzed in Figure 4. The pre-AD law curves are, of course, identical to those in Figure 3. But expressions (34) and (13) indicate that the imposition of a cost-based AD law causes both curves to shift leftward. And this implies that the firm's total production falls. ${ }^{30}$ Under perfect competition at home, then, a pricebased $\mathrm{AD}$ threat leaves total output unchanged because the firm's activity in the home market has no effect on the dumping threshold. When the rule is MC-based, however,

30) Further, it appears that the possibility of both $y_{1}$ and $y_{2}$ falling cannot be ruled out (as drawn both $y_{1}$ and $y_{2}$ fall, but this need not occur). It can be: demonstrated. however. that $y_{2}$ must fali. To see this. first observe: that $p_{1}=R_{2}^{* \prime}\left(y_{2}^{*}\right) E(\dot{e})$ by the first-order conditions for the pre-AD law problem, where $y_{2}^{*}$ is the quantity allocated to the: foreign market. Further, since the $A D$ constraint is assumed to be binding over some interval of realizations for $i$ given the pre-AD li2w choice: $\left(y_{1}^{*}, y_{2}^{*}\right)$, we also know that

$$
\left.R_{2}^{* \prime}\left(y_{2}^{*}\right) E(i)\right)>R_{2}^{* \prime}\left(y_{2}^{*}\right) \int_{\frac{c\left(y_{1}^{*}+y_{2}^{*}\right)}{j_{2}^{*}\left(y_{2}^{*}\right)}}^{\infty} c d F(c) . \quad \text { (continued next pagce) }
$$


reducing output below the unthreatened optimum has value since the dumping threshold depends on the firm's marginal costs.

\subsection{Perfect Competition at Home and Abroad}

Finally, consider a firm facing both a perfectly competitive domestic and foreign market, still assuming that these markets are segmented so that ex post price disparities can arise. ${ }^{31}$ Assume that price parity is expected to hold on average by some firms, i.e., that $p_{1}=$ $E(\tilde{e}) p_{2}^{\times}$(This is just an average version of the Law of One Price). A risk-neutral firm will be indifferent to the allocation of output between the home and foreign markets prior to the imposition of $\mathrm{AD}$ legislation. Any allocation of total output satisfying $p_{1}=C^{\prime}(y)$ is optimal. The introduction of either a cost-based or a price-based AD law acts, in effect, to reduce the expected price in the foreign market. If subjective expectations remain such that $p_{1}=E(\tilde{e}) p_{2}^{*}$, the firm will unambiguously produce exclusively for the home market. The indeterminacy of the case prior to $\mathrm{AD}$ legislation disappears, and an exclusive preference for the home market emerges. The firm's output is unchanged, continuing to satisfy $p_{1}=C^{\prime}(y)$.

The razor's edge described here is contingent upon the firm's expectations being consistent with expected price parity. More generally, expectations across firms will be diverse with some believing $p_{1}<E(\tilde{e}) p_{2}^{\star}$, some believing $p_{1}>E(\tilde{e}) p_{2}^{*}$, and some expecting price parity. Those firms expecting a relatively strong domestic currency (such that $\left.p_{1}>E(\tilde{e}) p_{2}^{*}\right)$ will produce exclusively for the home market before and after the $\mathrm{AD}$ legislation. Other

Also observe: that

$$
\int_{\frac{C\left(m_{1}+y_{2}\right)}{J_{2}^{*}\left(m_{2}\right)}}^{\infty} c d F(c) \leq E(\bar{c})
$$

for all $y_{1}$ and $y_{2}$, where the equality holds only if $y_{1}$ and $y_{2}$ are selected so as to eliminate: the: subjective possibility of an $\mathrm{AD}$ action being invoked. Finally, note that the first-order conditions for the post-AD law problem require that

$$
p_{1}=R_{2}^{* \prime}\left(y_{2}\right) \int_{\frac{c\left(y_{1}+y_{2}\right)}{p_{2}^{*}\left(y_{2}\right)}}^{\infty} \operatorname{ddF(s)}
$$

where $y_{1}$ and $y_{2}$ solve this problem. Then, since: $R_{2}^{* \prime \prime}\left(y_{2}\right)<0$ (the: marginal revenue: curve: is declining), by ecpuation $(\dagger)$ above we can conclude: that this condition can be restored only by reducing $y_{2}$ below $y_{2}^{*}$ so as to increase: $R_{2}^{* \prime}$.

31 Again, we abstract from the rationale: for invoking $A D$ in this casc: 
firms expecting a relatively weak domestic currency (such that $p_{1}<E(\tilde{e}) p_{2}^{*}$ ) will produce exclusively for the foreign market before the $\mathrm{AD}$ law. After the $\mathrm{AD}$ law is imposed, the latter firms may redirect output exclusively to the home market, may be moved to indifference concerning the allocation of product, or may continue selling exclusively abroad. In any case, because the $\mathrm{AD}$ law acts to reduce the expected price received for each unit sent abroad, its passage causes these firms to reduce production, with a lower limit established by the nonstochastic home price. ${ }^{32}$ Hence, if exchange-rate expectations are diverse across firms the competitive market conditions described here suggest that some firms will tend to cut back production but may continue selling exclusively abroad. Others may cut back production to the minimum level established by $p_{1}=C^{\prime}(y)$ and begin selling exclusively in the home market. And still other firms (those whose expectations satisfy $p_{1}=E(\tilde{e}) p_{2}^{*}$ ) will sell exclusively in the home market with production unchanged. On net, production falls.

These implications are quite consistent with our findings in the case of perfect competition at home and market power abroad. There we found that production is unchanged with the imposition of a price-based $\mathrm{AD}$ law and that firms will recoil somewhat from the foreign market. Here, production is unchanged for every firm that was not producing exclusively for the foreign market prior to the $\mathrm{AD}$ legislation.

\section{CONCLUDING REMARKS AND IMPLICATIONS FOR FURTHER RESEARCH}

Our analysis indicates that the general effect of an $\mathrm{AD}$ law as implemented in practice is to induce foreign firms to recoil (on the margin) from the export market. This is not surprising. What is interesting is the sensitivity of the firm's production response to the exact specification of the $\mathrm{AD}$ law, as well as to market structure and timing issues. We discovered that the optimal response to a price-based AD law in the short-run is to increase production and to "dump" it on the home market, as long as the firm has some domestic market power. The reason for this preemptive home dumping response is that by stepping up production for the domestic market the firm can optimally depress the home price and,

$32 p_{1}=C^{\prime}\left(y^{*}\right)$ defines the lower limit of production. 
thereby, mitigate the dumping threat. In a longer-run time frame the tendency is for production to decline or remain unchanged. Production is unaffected by the imposition of a price-based $\mathrm{AD}$ law if the exporter is a price taker in the home market. Under marginal- or average-cost based dumping, we found that the exporter's home market is insulated from $\mathrm{AD}$ legislation in the sense that domestic supply remains unchanged if marginal cost is constant.

It was noted that in many situations the foreign firm may be able to avoid an $A D$ action by adjusting its home production instrument. This was the case under price-based AD laws as long as exporting firms exercise some market power at home. The threat of price-based $\mathrm{AD}$ actions in such cases may not have the desired effect as far as import-competing furms are concerned. After all, an effective threat from the perspective of import-competing firms is one that induces foreign exporters to recoil sharply from the threatening market. Under a price-based rule, as pointed out, alternatives to recoiling from the foreign market exist. By adjusting total output and domestic supply, exporting firms may be able to mitigate the AD threat while pulling less product from the foreign market than otherwise. This result was identified as the home market effect.

If a marginal cost rule were to be implemented, the same conclusion would apply under decreasing marginal costs. By increasing total production the exporting firm is able to lessen the likelihood of an ex post $\mathrm{AD}$ action while also making the consequences of such an action less severe. Again, pulling product from the foreign market is but one measure available to an exporting firm under threat of $\mathrm{AD}$ actions. Even though of only hypothetical interest, a marginal-cost based $\mathrm{AD}$ law may be suboptimal if the intent of such legislation is to lessen foreign competition without actually having to undertake $\mathrm{AD}$ actions too frequently. As the issue of predatory behavior (predatory dumping) is most likely to arise for firms found to be selling below marginal cost, it is of some interest that even a marginal cost-based AD law may provide little relief from foreign competition in the ex ante sense.

If an average cost rule is followed, foreign firms no longer can mitigate the $\mathrm{AD}$ threat directly by adjusting total output and domestic supply. The home market now is insulated 
from the foreign $\mathrm{AD}$ law in the sense that independent variations of supply in the exporter's home market cannot mitigate the $\mathrm{AD}$ threat. Production at home does, however, decline. Also note that a rule based on the minimum LRATC eliminates the intra-period incentive to increase output for the home market. The effectiveness of the AD threat is not offset by a countervailing home market effect under an average cost rule.

Thus, it appears that there exists an incentive for import-competing firms to signal their preference for $\mathrm{AD}$ investigations that use an average cost rule. It would be interesting to see to what extent data exist that bolster the prediction that, if possible, average-cost based investigations are chosen by import-competing firms. The effect of average costbased AD actions is similar to voluntary export restraint (VER) agreements and safeguard (escape clause) actions. Similarities and differences are addressed in Hoekman and Leidy (1988). The general questions are: How do various instruments of contingent protection affect production and exporting decisions and what incentives face import-competing firms to seek alternative forms of relief. As argued in Hoekman (1988), in practice AD actions can be regarded as a substitute for safeguard (escape clause) actions. Also, the threat of an $\mathrm{AD}$ action may be sufficient inducement for an exporter to agree to a VER. This is clearly another avenue of harassment. In general, we believe that research on the incentive effects of alternative rules for contingent protection is a fruitful area for further research, both from a theoretical and a policy perspective. 


\section{REFERENCES}

Bernhardt, Dan, "Dumping, Adjustment Costs and Uncertainty," Journal of Economic Dynamics and Control, 8, 1984.

Blair, Roger D. and Leornard Cheng, "On Dumping," Southern Economic Journal, January 1984.

Caine, Wesley K., "A Case for Repealing the Antidumping Provisions of the Tariff Act of 1930," Law and Policy in International Business, vol. 13:681, 1981.

Dale, Richard, Anti-Dumping Law in a Liberal Trade Order, New York: St Martins Press, 1980.

Dickey, William, "Antidumping: Currency Fluctuations as a Cause of Dumping Margins," The International Trade Journal, 7, 1982.

Davies, Stephen W., and Anthony J. McGuinness, "Dumping at Less than Marginal Cost," Journal of International Economics, 12, 1982.

Ethier, Wilfred J., "Dumping," Journal of Political Economy, vol. 90, no. 31, 1982.

Finger, J. Michael, "The Industry-Country Incidence of 'Less than Fair Value' Cases in U.S. Import Trade," Quarterly Review of Economics and Business, vol. 21, no. 2, 1981.

Finger, J. Michael, "Antidumping and Antisubsidy Measures," in Finger and Olechowski (ed.), The Uruguay Round: A Handbook for Multilateral Trade Negotiations, Washington: The World Bank, 1987.

Finger, J.M., H. Keith Hall, and Douglas R. Nelson, "The Political Economy of Administered Protection," American Economic Review, June 1982.

Gregory, Gene, "The Profits of Harassment," Far Eastern Economic Review, October 1979.

Herander, Mark G., and J. Brad Schwartz, "An Empirical Test of the Impact of the Threat of U.S. Trade Policy: The Case of Antidumping Duties," Southern Economic Journal, 
July 1984.

Hoekman, Bernard M., "The Uruguay Round of Multilateral Trade Negotiations: Investigating the Scope for Agreement on Safeguards, Services, and Agriculture," The University of Michigan, manuscript, May 1988.

Hoekman, Bernard M. and Michael P. Leidy, "Incentive Effects of Alternative Rules for Contingent Protection," mimeo, July 1988.

Hillman, Arye L. and Eliakim Katz, "Domestic Uncertainty and Foreign Dumping," Canadian Journal of Economics, August 1986.

Katz, E., J Paroush and N. Kahana, "Price Uncertainty and the Price Discriminating Firm in International Trade," International Economic Review, June 1982.

Stern, Robert M., John H. Jackson and Bernard M. Hoekman, An Assessment of the GATT Codes on Non-tariff Measures. Thames Essay No. 55. Aldershot: Gower, for the Trade Policy Research Centre, 1988.

Vermulst, Edwin, Antidumping Law and Practice in the United States and the European Community. Amsterdam: North Holland, 1987.

Webb, Michael A., "Anti-Dumping Laws, Production Location and Prices," Journal of International Economics, 22, 1987. 


\section{TABLE 1}

Antidumping Actions by Major Users, 1980-86

\begin{tabular}{|c|c|c|c|c|}
\hline $\begin{array}{l}\text { Initiating } \\
\text { Country' }\end{array}$ & $\begin{array}{l}\text { Number } \\
\text { Initiated }\end{array}$ & $\begin{array}{l}\text { Affirmative } \\
\text { Determination }\end{array}$ & $\begin{array}{c}\text { Negative } \\
\text { Determination }\end{array}$ & $\begin{array}{l}\text { Outcome } \\
\text { Pending }\end{array}$ \\
\hline $\begin{array}{l}\text { Australia } \\
\text { Canada } \\
\text { EEC } \\
\text { LSA } \\
\text { Other }\end{array}$ & $\begin{array}{r}416 \\
230 \\
280 \\
350 \\
12\end{array}$ & $\begin{array}{r}219 \\
140 \\
213 \\
195 \\
8\end{array}$ & $\begin{array}{r}175 \\
88 \\
74 \\
137 \\
3\end{array}$ & $\begin{array}{r}46 \\
8 \\
47 \\
39 \\
2\end{array}$ \\
\hline Total & 1288 & 775 & 477 & 142 \\
\hline
\end{tabular}

Source: Finger (1987). 
FIGURE 1

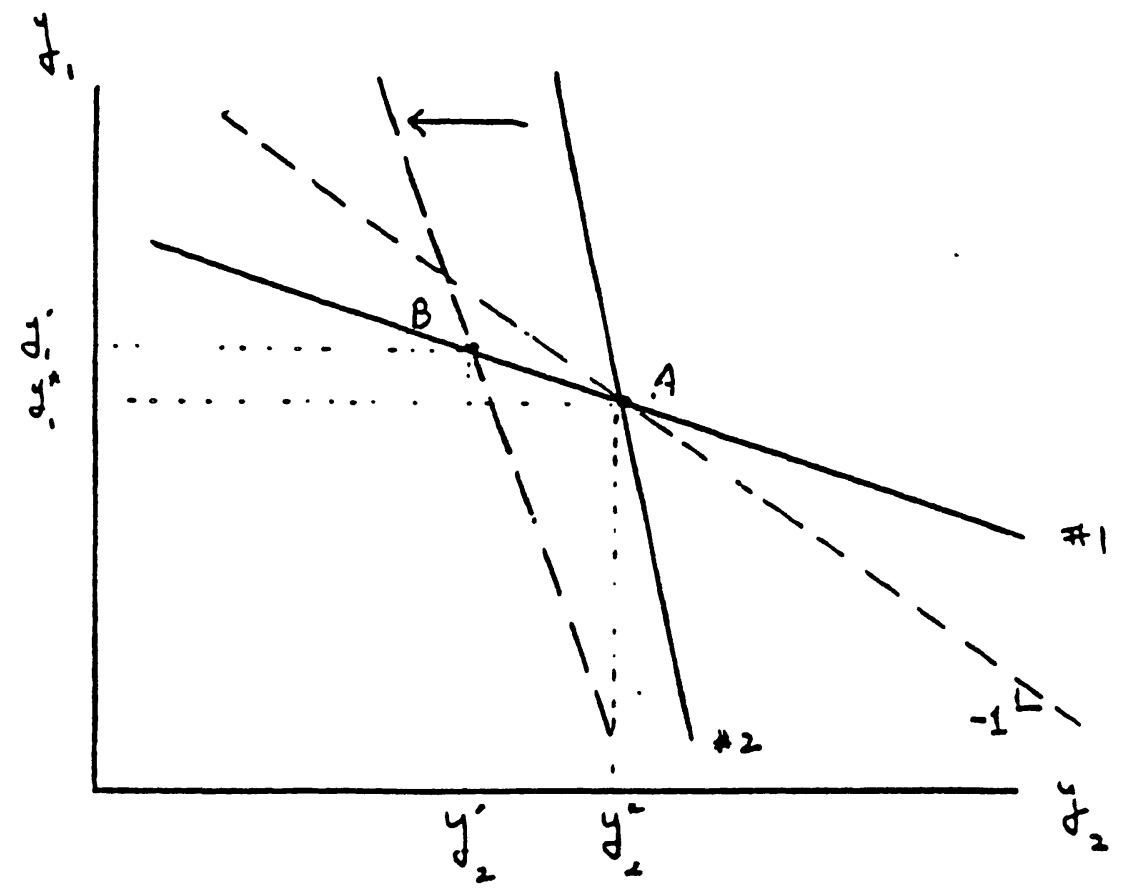


FIGURE 2

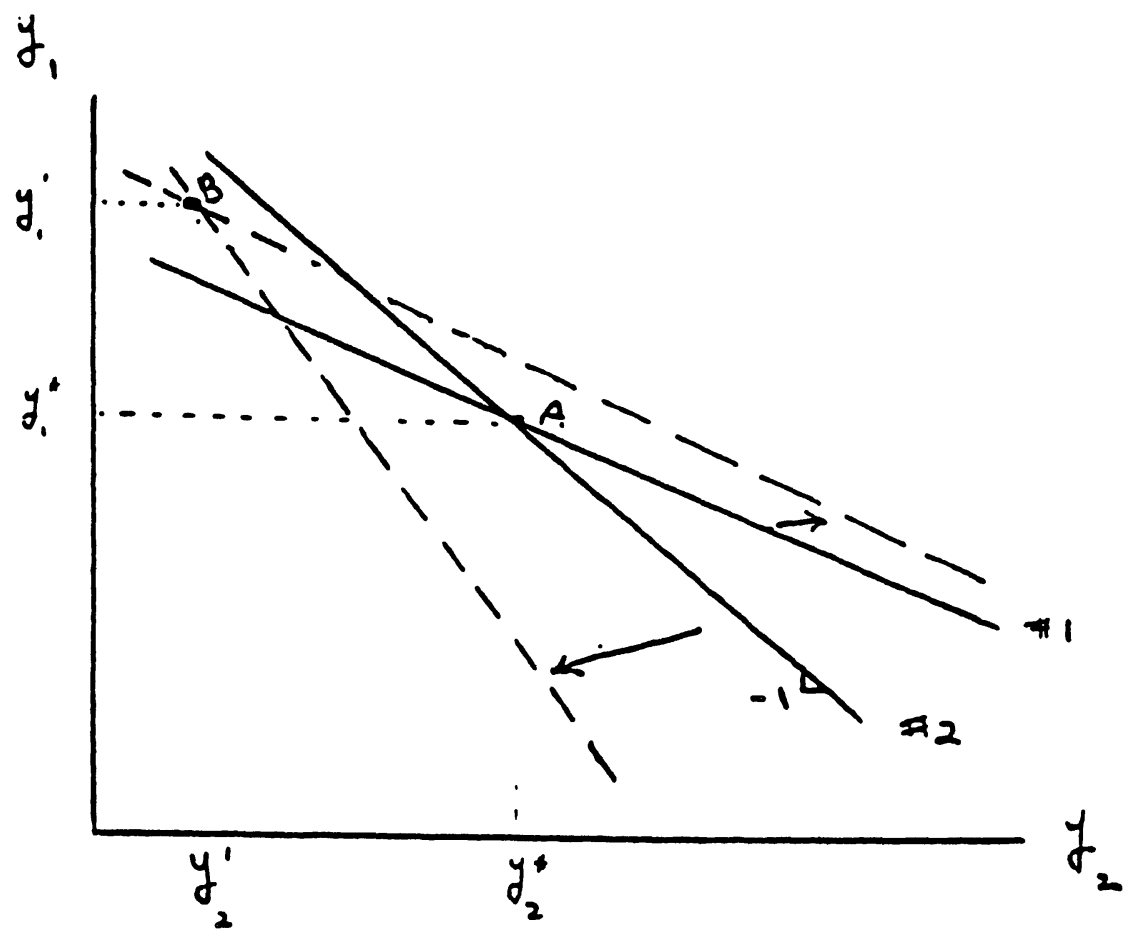


FIGURE 3

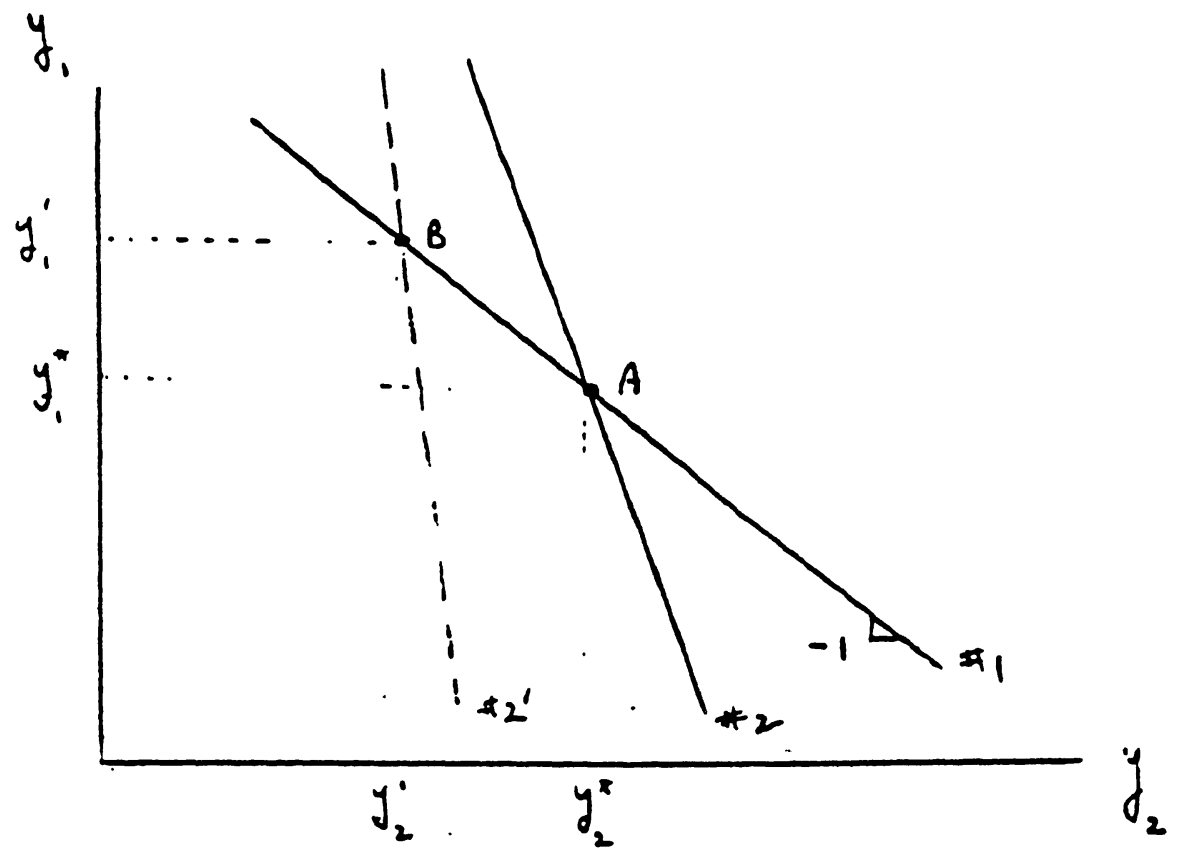




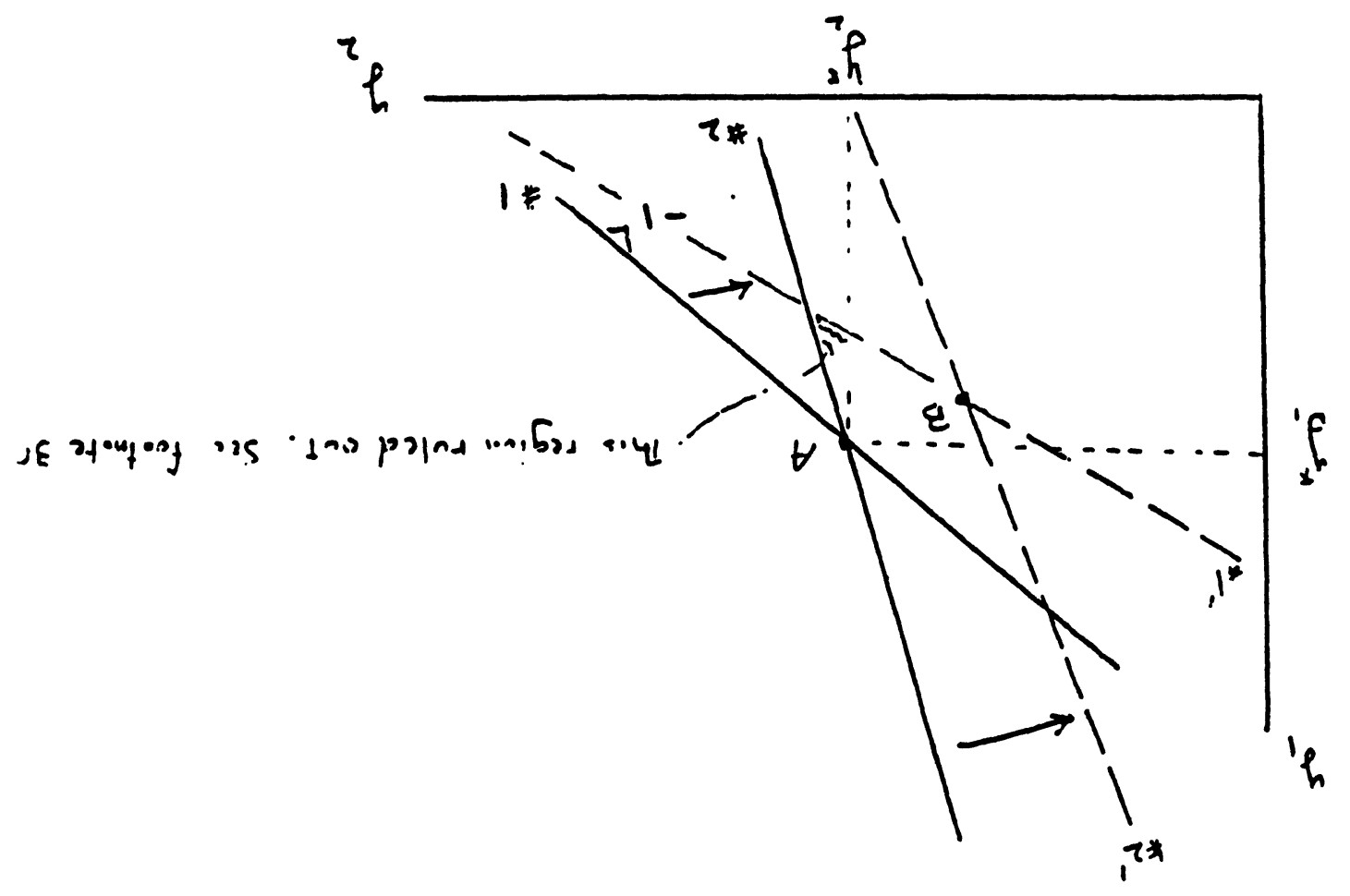

สมภอI 



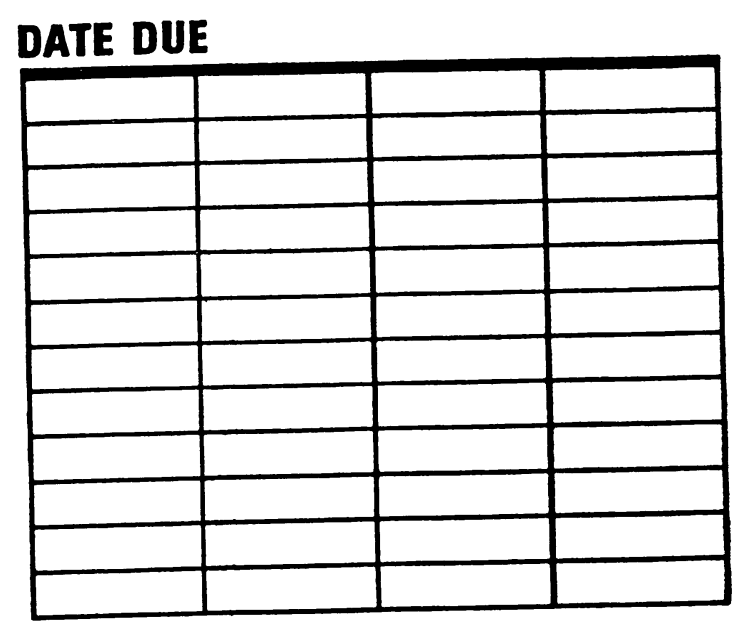


